\title{
Improving fenugreek plants growth and productivity via humic acid treatment
}

\author{
Emad El-Deen T. Ahmed ${ }^{1}$, Husain Abd El-Galeel ${ }^{2}$, Mahmoud A-H. Mohmed ${ }^{1}$, Salma Usama \\ Sayed $^{1}$
}

${ }^{1}$ Hort. Dept., Fac. of Agric., Minia Univ., ${ }^{2}$ Food Sci. Dept., Fac. of Agric., Minia Univ.

Received on: 23-4-2021

Accepted on: 14-5-2021

\begin{abstract}
Fenugreek is a commonly consumed herb due to its medicinal properties and nutritional value. Humic acid (HA) at 0, 50, 100, 200, 300 and $400 \mathrm{ppm}$ were applied as a seed priming, soil addition, foliar spray, seed priming + soil addition and soil addition + foliar spray. Both of HA concentrations and method of applications significantly improved plant growth and productivity. Moreover, there was a significant interaction between the two investigated factors. Plant height, plant dry weight, number of pods/plant and seed yield were generally increased by increasing HA concentrations regardless the method of applications. Soil addition had the highest significant values for all investigated traits regardless the concentration of HA. Overall, plants which treated with $400 \mathrm{ppm}$ HA as soil addition + foliar spray had the highest significant number of pods/plant (257.77) and seed yield (68.09 g/plant). Whereas, HA-untreated plants had the lowest values (71.27 pod/plant and $21.33 \mathrm{~g} / \mathrm{plant})$. Overall plants treated with $400 \mathrm{ppm}$ HA as a soil addition and foliar spray had the highest yield $2587 \mathrm{~kg} / \mathrm{fed}$. however, control plants which developed from priming seeds had the lowest yield $746 \mathrm{~kg} / \mathrm{fed}$. Therefore, it is recommended to treated fenugreek plant with HA as a soil addition and foliar spray three times during the growth season to increase seed yield by about 3-fold compared with untreated plants.
\end{abstract}

KEYWORDS:

\section{INTRODUCTION}

Fenugreek plant (Trigonella foenumgraecum L.), is an annual herb of Fabaceae family. It is native to the Mediterranean area and widely grown in many countries (De Candolle, 1964). Stems, leaves, seeds and twigs of the plant are used for cooking and medicinal properties. Both of seeds and leaves of fenugreek plants have a high medicinal and nutritional value. The seeds are a rich source of carbohydrates, lipids, proteins, mucilaginous fibre, vitamins $\mathrm{A}$ and $\mathrm{C}$, calcium, iron, and other nutritional minerals (Sauvaire et al., 1976 ; Billaud and Adrian, 2001). Dahanukar et al. (2000) added that they are also, rich in many secondary metabolites, such as trigonelline, coumarin, saponins, nicotinic acid, sapogenins, and phytic acid. Fenugreek is consumed to prevent constipation, improve digestion, stimulate the liver and spleen, increase the erythrocyte insulin receptors, enhance pancreatic function, purify the blood and improve appetite (Ahmadiani et al., 2001 ; Randhir et al., 2004).

Humic acid (HA) has been known since long time as vital contributors to soil fertility. Acting as a soil physicochemical and biological amendment it improves crop growth and productivity (Canellas et al., 2015). Humic acid is an outstanding natural and organic way to provide plants and soil with a concentrated dose of nutrients, vitamins and trace elements. Furthermore, it improves the uptake of micro- and macronutrients, by enhancing soil cation exchange capacity, and $\mathrm{P}$ availability via interfering with calcium phosphate precipitation (Trevisan et al., 2010; Jindo et al., 2012).

Different HA products are widely offered commercially for soil and foliar application. Rose et al. (2014) reviewed the response of different crops to HA application and concluded that the biomass of many crops was increased, but the responses were highly variable depending on the type of crop and environmental conditions. Halpern et al. (2015) and Canellas et al. (2015) reviewed agricultural application of HA, citing many examples where yield and quality of different horticultural crops were improved. They elucidated complex interactions between plants and HA which finally stimulated their growth with variation based on doses and times of applications. Lyons and Genc (2016) and Olk et al. (2018) showed favorable plant responses to commercial HA products but they emphasized inconsistency, mentioning that they 


\section{Scientific Journal of Agricultural Sciences 3 (1): 15-22, 2021}

often improve crop yield through alleviation of different environmental stresses.

On mungbean plants Waqas et al. (2014) emphasis that humic acid as seed priming, foliar spray or soil addition significantly improved number of pods/plant, seeds/pod and seed yield. However, the biological yield was not significantly affected by method of applications. Soil addition of HA 1, 2 or 3 $\mathrm{kg} / \mathrm{ha}$ resulted in higher number of pods/plant and grain yield, with no statistically difference among these concentrations. Dawood et al. (2019) showed that foliar spray of faba bean plants with $5 \mathrm{ml} / 1 \mathrm{HA}$ significantly improved vegetative growth traits, yield, and some chemical constitutes of seeds. Humic acid as a foliar application increased soybean yield but never influenced seed oil concentration. However, seed protein content was reduced depending on the environmental conditions (Lenssen et al., 2019). Kahraman (2017) treated chickpea seeds with $\mathrm{HA}$ at $0,60,90$ and $120 \mathrm{~kg} / \mathrm{h}$ divide into 2 doses (pre-sowing and pre-flowering) and found a positive effect of the treatments depending on the concentration.

Therefore, this study was conducted to assess the effects of different concentrations of HA and method of application: seed priming, soil addition, and foliar application on growth and productivity of fenugreek plants.

\section{MATERIAL AND METHODS}

This investigation was carried out during the two consecutive seasons 2017/2018 and 2018/2019 at the nursery and laboratory of ornamental plants, Fac. of Agric., Minia Univ. The physical and chemical analysis of the experimental soil described by Black et al. (1981) is shown in table 1.

Table 1. Physical and chemical analysis of the experimental soil

\begin{tabular}{|c|c|c|c|}
\hline Soil characters & Value & Soil characters & Value \\
\hline Soil type & Clay loam & Avail. P (\%) & 15.40 \\
\hline Sand $(\%)$ & 28.59 & Exch. K (mg/100g) & 2.45 \\
\hline Silt $(\%)$ & 30.29 & Exch. $\mathrm{Ca}(\mathrm{mg} / 100 \mathrm{~g})$ & 31.43 \\
\hline Clay & 41.12 & Exch. Na (mg/100g) & 2.46 \\
\hline Organic Matter (\%) & 1.65 & $\mathrm{Fe}$ & 8.39 \\
\hline $\mathrm{CaCo}_{3}(\%)$ & 2.10 & $\mathrm{Cu}$ & 2.04 \\
\hline $\mathrm{PH}(1: 2.5)$ & 7.79 & DIFA & 2.81 \\
\hline $\mathrm{EC}(\mathrm{mmhos} / \mathrm{cm})$ & 1.06 & Ext.(ppm) & 8.19 \\
\hline Total N (\%) & 0.08 & & \\
\hline
\end{tabular}

A complete randomized block design with 3 replicates in a split plot arrangement was conducted. The main plot was $3.6 \times 4.2 \mathrm{~m}$ with $60 \mathrm{~cm}$ distance between the rows and $40 \mathrm{~cm}$ between the hills within the row. The main plot included 5 methods of HA application which were seed priming, soil addition, foliar spray, seed priming + foliar spray and soil addition + foliar spray. The subplot included 6 concentrations of HA $(0,50,100,200,300$, and 400 ppm). Therefore, the experiment included 30 treatments.

Seeds were primed for $24 \mathrm{~h}$ before sowing on HA concentrations using 2 liters for each $1 \mathrm{~kg}$ of seeds. Treated seeds were sown on $26^{\text {th }}$ Oct. in both seasons and plants were thinned twice, finally each hill contained 2 plants. Plants received thrice foliar sprays of HA concentrations with 2 weeks intervals, till run off starting on $23^{\text {rd }}$ Nov. For soil application $50 \mathrm{ml}$ of HA was added around the base of the plant three times on the same time of foliar treatment.

All plants received NPK fertilizers at 50 $\mathrm{kg} / \mathrm{fed}$. of ammonium sulphate $(20.6 \% \mathrm{~N}), 200$ $\mathrm{kg} / \mathrm{fed}$. of calcium superphosphate $\left(15.5 \% \mathrm{P}_{2} \mathrm{O}_{5}\right)$ and $50 \mathrm{~kg} / \mathrm{fed}$. of potassium sulphate $\left(\begin{array}{ll}48 \% & \mathrm{~K}_{2} \mathrm{O}\end{array}\right)$. Phosphorus fertilizer was added during preparing of the soil to cultivation, while $\mathrm{K}$ fertilizer was added on $26^{\text {th }}$ November in both growing seasons. The $\mathrm{N}$ fertilizer was divided into two batches, added with 3 weeks intervals, starting on $26^{\text {th }}$ Nov. All other agriculture practices were carried out following farmer habitat.

At maturity stage (25 ${ }^{\text {th }}$ March) plants were cut just above ground. Plant height was measured from the ground to the top most point of the plant. After harvesting, the plants were dried for several days to remove moisture from them. Individual plants were weighted to record dry weights after air-drying. Pods number and seed yield were assessed after their extracting manually from each plant and then weighted. The obtained data were tabulated and subjected to proper statistical and analysis according to Mead et al. (1993) using the statistical program MSTAT-C.

\section{RESULTS AND DISCUSSION}

\subsection{Plant height}

The analysis of variance showed that both of HA concentrations and method of application affected the height of fenugreek plant $(\mathrm{p} \leq 0.05)$. Moreover, there was a significant interaction between these two factors as shown in table 2, with a 
Table 2. Effect of concentrations and method of applications of humic acid on the plant height of fenugreek plant during two seasons.

\begin{tabular}{|c|c|c|c|c|c|c|}
\hline \multirow{2}{*}{$\begin{array}{c}\text { Humic acid } \\
\text { concentrations (ppm) } \\
\text { (B) }\end{array}$} & \multicolumn{5}{|c|}{ Method of applications (A) } & \multirow{2}{*}{$\begin{array}{l}\text { Mean } \\
\text { (B) }\end{array}$} \\
\hline & $\begin{array}{l}\text { Seed Priming } \\
\text { (SP) }\end{array}$ & $\begin{array}{l}\text { Soil Addition } \\
\text { (SA) }\end{array}$ & $\begin{array}{l}\text { Foliar Spray } \\
\text { (FS) }\end{array}$ & $\mathrm{SP}+\mathrm{FS}$ & $\mathrm{SA}+\mathrm{FS}$ & \\
\hline \multicolumn{7}{|c|}{ First season $(2017 / 2018)$} \\
\hline 0 & 63.02 & 62.51 & 64.00 & 63.55 & 64.01 & 62.50 \\
\hline 50 & 69.61 & 70.44 & 72.07 & 76.91 & 79.31 & 73.67 \\
\hline 100 & 73.53 & 76.18 & 77.90 & 84.54 & 87.02 & 79.83 \\
\hline 200 & 78.21 & 82.72 & 87.89 & 95.05 & 95.29 & 87.83 \\
\hline 300 & 82.76 & 89.49 & 95.62 & 103.31 & 104.92 & 95.22 \\
\hline 400 & 88.10 & 95.12 & 106.22 & 110.60 & 115.30 & 103.07 \\
\hline Mean (A) & 75.09 & 79.41 & 84.01 & 88.99 & 90.65 & \\
\hline L.S.D. at $5 \%$ & & $: 1.21$ & : 1.72 & $\mathrm{AB}: 3.84$ & & \\
\hline \multicolumn{7}{|c|}{ Second season (2018/2019) } \\
\hline 0 & 62.56 & 61.53 & 63.51 & 61.93 & 64.22 & 62.7 \\
\hline 50 & 68.84 & 69.87 & 72.69 & 76.55 & 79.43 & 73.5 \\
\hline 100 & 74.92 & 75.89 & 77.88 & 84.3 & 86.62 & 79.9 \\
\hline 200 & 80.92 & 83.34 & 87.42 & 94.85 & 95.49 & 88.4 \\
\hline 300 & 86.86 & 90.29 & 94.76 & 103.83 & 106.93 & 96.5 \\
\hline 400 & 93.51 & 99.19 & 107.69 & 106.93 & 116.93 & 104.8 \\
\hline Mean (A) & 77.94 & 80.02 & 83.99 & 96.53 & 105.72 & \\
\hline L.S.D. at $5 \%$ & & A: 1.57 & B: 1.23 & $\mathrm{AB}: 2.74$ & & \\
\hline
\end{tabular}

similar trend in both seasons. In the $1^{\text {st }}$ one, plant height was varied between 75.09 and $90.65 \mathrm{~cm}$ depending on the method of application. Humic acid-untreated plants had the shortest plant height $(62.50 \mathrm{~cm})$ which gradually increased to the maximum value $(103.07 \mathrm{~cm})$ once plants treated with the highest concentration of HA (400 ppm). Overall, there was no significant difference among method of application for plants treated with tap water. Almost any increase on HA concentrations was coincided with significant increase on plant height under any method of applications. The highest plant height $(115.30 \mathrm{~cm})$ being for plants treated with $400 \mathrm{ppm}$ of HA as a soil addition and foliar spray whereas, the shortest plants $(62.5 \mathrm{~cm})$ were those untreated with HA (Table 2).

\subsection{Plant dry weight}

The ANOVA showed a significant variation on fenugreek plants dry weights due to concentrations of HA as well as, method of applications. Moreover, there was a significant interaction between both factors. Generally, there was an increment on the plant dry weights by increasing concentrations of HA in both seasons. Overall, soil addition + foliar spray had the superior effect than the other method of applications under the same concentration of HA. In the $1^{\text {st }}$ season, plants developed from HA-untreated seeds under different method of applications had the lowest value $(19.65 \mathrm{~g})$ whereas, the highest one $(39.08 \mathrm{~g})$ was obtained when seeds were treated with $400 \mathrm{ppm}$ of HA as a soil addition + foliar spray. Regardless the method of applications there was a liner increase in plant dry weights by increasing concentrations of HA (Table 3). Similar results were achieved in the $2^{\text {nd }}$ season.

\subsection{Pod number}

Table 4 shows similar response trend for fenugreek plants to HA application in both experimental seasons. Concentrations of HA as well as method of applications significantly affected number of pods/plant which gradually increased by increasing the concentrations of HA. Also, there was a significant difference among the methods of applications. For example in the $1^{\text {st }}$ season increasing HA concentrations from zero to $400 \mathrm{ppm}$ increased number of pods from 71.37 to 163.13 pods/plant. Also, numbers of pods increased from 112.88/plant for seed priming treatment to 166.30 for plants received HA as a soil addition + foliar spray. Results showed a significant interaction between the two investigated factors. Regardless the method of applications almost any increase on HA concentrations increased the number of pods 
Table 3. Effect of concentrations and method of applications of humic acid on the dry weights (g/plant) of fenugreek plant during two seasons.

\begin{tabular}{|c|c|c|c|c|c|c|}
\hline \multirow{2}{*}{$\begin{array}{c}\text { Humic acid } \\
\text { concentrations (ppm) } \\
\text { (B) }\end{array}$} & \multicolumn{5}{|c|}{ Method of applications (A) } & \multirow[b]{2}{*}{$\begin{array}{l}\text { Mean } \\
\text { (B) }\end{array}$} \\
\hline & $\begin{array}{c}\text { Seed } \\
\text { Priming } \\
\text { (SP) }\end{array}$ & $\begin{array}{c}\text { Soil } \\
\text { Addition } \\
\text { (SA) }\end{array}$ & $\begin{array}{l}\text { Foliar Spray } \\
\text { (FS) }\end{array}$ & $\mathrm{SP}+\mathrm{FS}$ & $\mathrm{SA}+\mathrm{FS}$ & \\
\hline \multicolumn{7}{|c|}{ First season (2017/2018) } \\
\hline 0 & 18.30 & 19.12 & 19.99 & 20.87 & 19.95 & 19.65 \\
\hline 50 & 21.11 & 23.00 & 23.59 & 23.80 & 25.02 & 23.30 \\
\hline 100 & 23.00 & 24.37 & 25.79 & 25.84 & 26.82 & 25.16 \\
\hline 200 & 25.25 & 26.95 & 27.97 & 29.04 & 29.92 & 27.83 \\
\hline 300 & 26.46 & 29.39 & 31.04 & 33.12 & 34.56 & 30.91 \\
\hline 400 & 29.10 & 34.91 & 32.79 & 37.07 & 39.08 & 34.59 \\
\hline Mean (A) & 23.87 & 26.29 & 26.86 & 28.29 & 29.23 & \\
\hline L.S.D. at $5 \%$ & & A: 1.77 & B: 0.87 & $\mathrm{AB}: 1$ & & \\
\hline \multicolumn{7}{|c|}{ Second season $(2018 / 2019)$} \\
\hline 0 & 19.24 & 20.24 & 20.56 & 20.44 & 21.14 & 20.32 \\
\hline 50 & 21.17 & 22.71 & 23.55 & 24.44 & 24.57 & 23.29 \\
\hline 100 & 22.93 & 24.86 & 25.64 & 26.97 & 27.89 & 25.66 \\
\hline 200 & 25.72 & 28.17 & 30.34 & 31.51 & 33.95 & 29.94 \\
\hline 300 & 27.85 & 30.80 & 35.58 & 36.40 & 38.63 & 33.85 \\
\hline 400 & 29.65 & 34.24 & 39.25 & 41.78 & 44.69 & 37.92 \\
\hline Mean (A) & 24.43 & 26.84 & 29.15 & 30.26 & 31.81 & \\
\hline L.S.D. at $5 \%$ & & $: 1.91$ & B: 1.12 & AB: & & \\
\hline
\end{tabular}

Table 4. Effect of concentrations and method of applications of humic acid on the pod number of fenugreek plant during two seasons.

\begin{tabular}{|c|c|c|c|c|c|c|}
\hline \multirow{2}{*}{$\begin{array}{c}\text { Humic acid } \\
\text { concentrations (ppm) } \\
\text { (B) }\end{array}$} & \multicolumn{5}{|c|}{ Method of applications (A) } & \multirow[b]{2}{*}{$\begin{array}{c}\text { Mean } \\
\text { (B) }\end{array}$} \\
\hline & $\begin{array}{l}\text { Seed } \\
\text { Priming } \\
\text { (SP) }\end{array}$ & $\begin{array}{c}\text { Soil } \\
\text { Addition } \\
(\mathrm{SA})\end{array}$ & $\begin{array}{l}\text { Foliar Spray } \\
\text { (FS) }\end{array}$ & $\mathrm{SP}+\mathrm{FS}$ & $\mathrm{SA}+\mathrm{FS}$ & \\
\hline \multicolumn{7}{|c|}{ First season $(2017 / 2018)$} \\
\hline 0 & 89.68 & 88.52 & 89.09 & 88.62 & 90.54 & 71.37 \\
\hline 50 & 96.12 & 103.48 & 114.52 & 121.11 & 120.63 & 91.95 \\
\hline 100 & 107.96 & 112.50 & 129.40 & 137.85 & 145.30 & 105.01 \\
\hline 200 & 117.34 & 126.32 & 153.50 & 167.4 & 182.00 & 125.84 \\
\hline 300 & 127.56 & 140.48 & 172.08 & 192.16 & 221.58 & 145.26 \\
\hline 400 & 138.63 & 150.51 & 190.28 & 217.07 & 257.77 & 163.13 \\
\hline Mean (A) & 112.88 & 120.30 & 141.48 & 153.93 & 166.30 & \\
\hline L.S.D. at $5 \%$ & & A: 1.16 & B: 1.90 & AB 2.03 & & \\
\hline \multicolumn{7}{|c|}{ Second season $(2018 / 2019)$} \\
\hline Control & 91.02 & 90.5 & 89.37 & 90.14 & 91.72 & 90.75 \\
\hline 50 & 97.15 & 107.01 & 116.38 & 123.86 & 122.79 & 113.44 \\
\hline 100 & 109.96 & 115.35 & 130.47 & 141.01 & 147.96 & 128.95 \\
\hline 200 & 120.53 & 128.63 & 154.86 & 169.4 & 186.05 & 151.89 \\
\hline 300 & 129.73 & 142.2 & 174.02 & 190.42 & 223.66 & 172.01 \\
\hline 400 & 140.78 & 154.33 & 190.29 & 223.41 & 265.89 & 194.94 \\
\hline Mean (A) & 114.86 & 123.00 & 142.57 & 156.37 & 172.09 & \\
\hline L.S.D. at $5 \%$ & & A: 1.08 & B: 1.06 & AB 2.36 & & \\
\hline
\end{tabular}


$(\mathrm{P} \leq 0.5)$. The minimum number of pods was for HAuntreated plants with no significant difference due to method of applications. The highest number of pods (257.77 /plant) being for plants treated with $400 \mathrm{ppm}$ of HA as a soil addition and foliar spray. Similar results were observed in the $2^{\text {nd }}$ season (Table 4)

\subsection{Seed weight/plant}

Both of investigated factors increased $(p \leq 0.05)$ the yield of fenugreek seed/plant with a similar trend in both seasons. There was a significant interaction among these two factors. In the $1^{\text {st }}$ season, HA-untreated plants under different method of applications had similar yield (19.63 -22.50 g) with no significant difference among them. There was no significant effect of $50 \mathrm{ppm}$ HA on seed yield when it applied as a seed priming or soil addition whereas, other method of applications significantly increased seed yield. Under any method of applications seed yield significantly increased by the gradual increase of HA concentrations from 100 to $400 \mathrm{ppm}$. The highest yield in the two seasons (68.09 and $71.08 \mathrm{~g}$, respectively) was estimated for plants treated with $400 \mathrm{ppm} \mathrm{HA}$ as a soil addition + foliar spray. The second promising treatment was the same concentration of HA but applies as seed priming + foliar spray which yielded $62.86 \mathrm{~g} /$ plant (Table 5).

Table 5. Effect of concentrations and method of applications of humic acid on the seed yield (g/plant) of fenugreek plant during two seasons.

\begin{tabular}{|c|c|c|c|c|c|c|}
\hline \multirow{2}{*}{$\begin{array}{c}\text { Humic acid } \\
\text { concentrations (ppm) } \\
\text { (B) }\end{array}$} & \multicolumn{5}{|c|}{ Method of applications (A) } & \multirow[b]{2}{*}{$\begin{array}{l}\text { Mean } \\
\text { (B) }\end{array}$} \\
\hline & $\begin{array}{l}\text { Seed } \\
\text { Priming } \\
\text { (SP) }\end{array}$ & $\begin{array}{c}\text { Soil } \\
\text { Addition } \\
(\mathrm{SA})\end{array}$ & $\begin{array}{l}\text { Foliar Spray } \\
\text { (FS) }\end{array}$ & $\mathrm{SP}+\mathrm{FS}$ & $\mathrm{SA}+\mathrm{FS}$ & \\
\hline \multicolumn{7}{|c|}{ First season $(2017 / 2018)$} \\
\hline Control & 19.63 & 21.47 & 22.50 & 20.30 & 21.76 & 21.23 \\
\hline 50 & 21.81 & 23.89 & 25.28 & 26.02 & 30.13 & 25.43 \\
\hline 100 & 24.24 & 26.40 & 31.31 & 29.20 & 35.42 & 29.31 \\
\hline 200 & 28.79 & 29.67 & 37.59 & 38.47 & 43.38 & 35.58 \\
\hline 300 & 34.87 & 38.95 & 42.73 & 48.97 & 52.53 & 43.61 \\
\hline 400 & 40.23 & 47.73 & 57.19 & 62.86 & 68.09 & 55.26 \\
\hline Mean (A) & 28.26 & 31.38 & 36.10 & 37.64 & 41.05 & \\
\hline L.S.D. at $5 \%$ & & A: 0.71 & B: 1.05 & $\mathrm{AB} 2$ & & \\
\hline
\end{tabular}

\begin{tabular}{ccccccc}
\hline \multicolumn{7}{c}{ Second season $(2018 / 2019)$} \\
\hline Control & 20.39 & 21.33 & 21.74 & 22.15 & 22.51 & 21.62 \\
50 & 22.12 & 24.26 & 26.82 & 25.98 & 26.20 & 25.08 \\
100 & 23.51 & 27.12 & 31.34 & 34.51 & 34.84 & 30.26 \\
200 & 29.24 & 33.31 & 37.76 & 43.09 & 44.23 & 37.53 \\
300 & 34.47 & 43.78 & 45.02 & 53.50 & 54.94 & 46.34 \\
400 & 39.86 & 51.55 & 57.51 & 63.84 & 71.08 & 56.77 \\
Mean (A) & 28.27 & 33.56 & 36.70 & 40.51 & 42.30 & \\
L.S.D. at 5\% & & A: 0.86 & B: 0.92 & AB 2.05 & \\
\hline
\end{tabular}

\subsection{Seed yield/fed.}

Seed yield/fad had the same trend as the seed yield/plant (Table 6). The analysis of variance showed a significant effect of both factors with a significant interaction between them. Overall plants treated with $400 \mathrm{ppm} \mathrm{HA}$ as a soil addition + foliar spray had the highest yield 2587 and $2708 \mathrm{~kg} / \mathrm{fad}$ in both seasons, respectively. However, control plants which developed from priming seeds had the lowest yield 746 and $777 \mathrm{~kg} / \mathrm{fad}$ in both season, respectively, with no significant difference among control plants due to method of application.
Our results showed that the effect of HA on fenugreek plants was linearly correlated with its concentrations up to $400 \mathrm{ppm}$ which had the highest significant increase in plant heights and dry weights (63 and $77 \%$, respectively) over that of untreated plants in the $1^{\text {st }}$ season. This improvement in plant growth resulted in augmentation on number of pods and seed yield/plant which increased by 84 and $159 \%$, respectively with similar observation in the $2^{\text {nd }}$ season. The promotion effect of HA on many legume crops has been widely reported (Ashraf et al., 2005, Waqas et al., 2014; Karaman, 2017; Li et al., 2019). 
Table 6. Effect of concentrations and method of applications of humic acid on the seed yield (kg/fed.) of fenugreek plant during two seasons.

\begin{tabular}{|c|c|c|c|c|c|c|}
\hline \multirow{2}{*}{$\begin{array}{c}\text { Humic acid } \\
\text { concentrations (ppm) } \\
\text { (B) }\end{array}$} & \multicolumn{5}{|c|}{ Method of applications (A) } & \multirow[b]{2}{*}{$\begin{array}{c}\text { Mean } \\
\text { (B) }\end{array}$} \\
\hline & $\begin{array}{c}\text { Seed } \\
\text { Priming } \\
\text { (SP) }\end{array}$ & $\begin{array}{c}\text { Soil } \\
\text { Addition } \\
\text { (SA) }\end{array}$ & $\begin{array}{l}\text { Foliar Spray } \\
\text { (FS) }\end{array}$ & $\mathrm{SP}+\mathrm{FS}$ & $\mathrm{SA}+\mathrm{FS}$ & \\
\hline \multicolumn{7}{|c|}{ First season $(2017 / 2018)$} \\
\hline Control & 746 & 816 & 855 & 771 & 827 & 807 \\
\hline 50 & 829 & 908 & 961 & 989 & 1145 & 966 \\
\hline 100 & 921 & 1003 & 1190 & 1110 & 1346 & 1114 \\
\hline 200 & 1094 & 1127 & 1428 & 1462 & 1648 & 1352 \\
\hline 300 & 1325 & 1480 & 1624 & 1861 & 1996 & 1657 \\
\hline 400 & 1529 & 1814 & 2173 & 2389 & 2587 & 2100 \\
\hline Mean (A) & 1074 & 1192 & 1372 & 1430 & 1592 & \\
\hline L.S.D. at $5 \%$ & & A: 27 & B: 37 & $\mathrm{AB} 83$ & & \\
\hline
\end{tabular}

Second season $(2018 / 2019)$

\begin{tabular}{ccccccc}
\hline Control & 777 & 812 & 828 & 844 & 858 & 824 \\
50 & 843 & 924 & 1022 & 989 & 998 & 955 \\
100 & 896 & 1033 & 1194 & 1314 & 1327 & 1153 \\
200 & 1114 & 1269 & 1438 & 1641 & 1685 & 1429 \\
300 & 1313 & 1667 & 1715 & 2038 & 2063 & 1759 \\
400 & 1549 & 1964 & 2191 & 2432 & 2708 & 2169 \\
Mean (A) & 1082 & 1278 & 1398 & 1543 & 1607 & 1381 \\
L.S.D. at 5\% & \multicolumn{2}{c}{ A:39.61 } & B:35.78 & AB:80.01 & & \\
\hline
\end{tabular}

Besides enhancement nutrients uptake with HA application Rose et al. (2014) and Vista (2017) suggested that it also, contributes to cell wall loosening, cell enlargement leading to organ growth. Another explanation for increasing plant height and biomass might that $\mathrm{HA}$ act in mode like plant growth substances (O'Donnel, 1973; Casenave de Sanfilippo et al., 1990)

Obtained data showed that methods of HA application had a significant effect on all estimated traits. Seed priming had the lowest effect followed by the soil addition. Yet, the dual treatment (soil addition + foliar spay) was the superior one as it increased number of pods and seed yield/plant by 50 and $50 \%$, respectively, over that of seed priming treatment, in the $1^{\text {st }}$ season. The superiority of different application methods over the seed priming one could be due to that plants developed form primed seeds had the minimum dose of HA compared with soil addition as plants on the last treatment which received three doses. Similarly foliar spray treatments provided plants with higher quantity of HA. Moreover, when applying HA as a foliar treatment some of it also reaches to the soil that could make a synergetic effect during uptake of nutrients (David et al., 1994). For the same reason, results could explain why the dual treatments were superior to single one. Kaya et al. (2005) suggested existence of synergetic effect of mutual applications of HA and mineral nutrients.

Recent results are in line with those found by Kahraman (2017) and Ashraf et al. (2005) as soil application yielded significantly higher yield than foliar spray which was better than seed priming one. However, in all cases the response depended on the dose of application. Nonetheless, our results do not agree with those of Waqas et al. (2014) on mungbean as method of application did not affect the biological yield. Foliar uptake of nutrients is widely accompaniments standard root fertilizer application (Peigne et al., 2018) and recently Smilkova et al. (2019) confirmed the uptake of humic substance via cuticular diffusion.

The current study revealed a significant interaction between HA concentrations and methods of applications for all investigated traits. Overall, number of pods and seed yield/plant for plants treated with $400 \mathrm{ppm}$ HA as a soil addition + foliar spray were increased in the $2^{\text {nd }}$ season by 187 and $240 \%$ respectively over that of the untreated plants with similar improvement in the $1^{\text {st }}$ season. Overall, in that season plants treated with $400 \mathrm{ppm} \mathrm{HA}$ as a soil addition + foliar spray had the highest yield $2587 \mathrm{~kg} / \mathrm{fed}$. However, control plants which developed from priming seeds had the lowest yield 
746 with no significant difference among control plants due to method of application

Li et al. (2019) explained the mechanism of improving of peanut crop following HA fertilization by evaluating various soil characters and concluded that it amplified soil N, P and $\mathrm{K}$ contents and availability. Likewise, the stimulating response of HA has been partially related to enhance uptake of macro and microelements (Calov et al., 2014 ; Canellas et al., 2014; Yakhin et al., 2017; Halpern et al., 2017).

As a conclusion this study suggested that treated fenugreek plants with humic acid at $400 \mathrm{ppm}$ as a soil addition + foliar application three times during the growth season could significantly improve the plant growth. This treatment increased seed yield more than 3-fold than plants developed from HA-priming seed.

\section{REFERENCES}

Ahmadiani A, Javan M, Semnanian S, Barat E and Kamalinejad M (2001). Anti-inflammatory and antipyretic effects of Trigonella foenumgraecum leaves extract in the rat. $\mathrm{J}$ Ethnopharmacol., 75: 283-286.

Ashraf M, Nasir S. Sarfaraz TS (2005). Biological effect of biofertilizer humic acid on mungbeans. Inter. J. of Biology and Biotechnol., 2: 737-739.

Billaud C, Adrian J (2001). Fenugreek composition, nutritional value and Physiological properties. Sci. Aliments., 21: 3-26.

Black CA, Evans DD, Ensminger LE, White GL, and Clark FE (1981). Methods of Soil Analysis. Part 2, Agron. Inc. Madison. Wisc., USA. Pp.1-100

Calvo P, Nelson L, Kloepper JW (2014). Agricultural uses of plant biostimulants. Plant Soil., 383: 3-41.

Canellas LP, Olivares FL, Aguiar NO, Jones DL, Nebbioso A, Mazzei P, Piccolo A. (2015). Humic and fulvic acids as biostimulants in horticulture. Sci Hortic., 196:15-27.

Casenave deSanfillipo E, Arguello JA, Abdala G and Orioli GA. (1990). Content of auxin-inhibitor and gibberellin like substances in humic acids. Biol. Pl., 32: 346-5.

Dahanukar SA, Kulkarni RA and Rege NN (2000). Pharmacology of medicinal plants and natural products. Indian J Pharmacol., 32: 81-118

David PP, Nelson PV and Sanders DC (1994). A humic acid improves growth of tomato seedling in solution culture. J. P1. Nutr., 17: 173-84

Dawood MG, Abdel-Baky YR, El-Awadi MES (2019). Enhancement quality and quantity of faba bean plants grown under sandy soil conditions by nicotinamide and/or humic acid application. Bull Natl Res Cent., 43: 28 https://doi.org/10.1186/s42269-019-0067-0
De Candolle A. (1964). Origin of cultivated plants. Hafner, New York. PP 468.

Haghighi S, Nejad TS, Lack S (2011). Effect of biological fertilizer of HA on metabolic process of biological nitrogen fixation. Life Science J., 8: 4348.

Halpern M, Bar-Tal A, Olek M, Minz D, Muller T, Yermiyahu $U$ (2015). The use of biostimulants for enhancing nutrient uptake. Adv. Agron., 130: 141-174.

Jindo K, Martim SA, Navarro EC, Aguiar NO, Canellas LP (2012). Root growth promotion by humic acids from composted and non-composted urban organic wastes. Plant Soil, 353: 209-220.

Kahraman A (2017). Effect of humic acid applications on the yield components in chickpea. J. of Agric. Faculty of Gaziosmanpasa Univ., 34: 218222.

Kaya M, Atak M, Khawar KM, Cemalettin Y, Özcan S. (2005). Effect of pre-sowing seed treatment with zinc and foliar spray of humic acids on yield of common bean (Phaseolus vulgaris L.). Inter. J. of Agric. \& Biology, 7: 875-878.

Lenssen AW, Olk DC, Dinnes DL. (2019). Application of a formulated humic product can increase soybean yield. CFTM 5:180053. doi: 10.2134/ cftm2018.07.0053

Li Y, Fang F, Wei J, Wu X, Cui R, Li G, Zheng F. (2019). Humic acid fertilizer improved soil properties and soil microbial diversity of continuous cropping peanut: A three-year experiment. Scientific Reports, 9:12014 https://doi.org/10.1038/s41598-019-48620-4

Lyons G, Genc Y (2016). Commercial humates in agriculture: Real substance or smoke and mirrors? A review. Agron 6: 50 . https://doi. org/10.3390/agronomy6040050

Mead R, Currow RN, Harted AM (1993). Statistical methods in agricultural and experimented biology and $2^{\text {nd }}$ Ed. Chapman and Hall, London, UK. pp 472.

O'Donnel RW (1973). The auxin like effects of humic preparations from leonardite. Soil Sci., 116: 106-12

Olk DC, Dinnes, DL, Rene Scoresby J, Callaway CR, Darlington, JW (2018). Humic products in agriculture: Potential benefits and research challenges- a review. J. of Soils and Sediments, 18: 2881-2891.

Peigne J, Vian JF, Payet V, Saby NPA (2018). Soil fertility after 10 years of conservation tillage in organic farming. Soil Tillage Res., 180:1-9.

Randhir R, Lin YT, Shetty K (2004). Phenolics, their antioxidant and antimicrobial activity in dark germinated fenugreek sprouts in response to peptide and phytochemical elicitors. Asia Pac J Clin Nutr., 13: 295-307. 
Rose MT, Patti AF, Little KR, Brown AL, Jackson WR, Cavagnaro TR (2014). A metaanalysis and review of plant growth response to humic substances: practical implications for agriculture. Adv. Agron., 124:37-89.

Sauvaire Y, Baccou JC, Besancon P (1976). Nutritional value of the properties of the fenugreek (Trigonella foenum-graecum L.). Nutr. Rep. Int., 14:527-537.

Smilkova M, Smilek J, Kalina M, Klucakova M, Pekar M, Sedlacek P (2019). A simple technique for assessing the cuticular diffusion of humic acid biostimulants. Plant Methods, 15: 1-11.

Trevisan S, Francioso O, Quaggiotti S, Nardi S (2010). Humic substances biological activity at the plant-soil interface: From environmental aspects to molecular factors. Plant Signal Behav., 5:635-643.

Vista SP (2017). Use of Humic Acid in Agriculture. In: A Handbook of Soil Science. Government of Nepal Nepal Agricultural Research Council (NARC) National Agriculture Research Institute (NARI), Soil Science Division Khumaltar, PP 6-22.

Waqas M, Ahmad B, Arif M. Munsif F, Khan AL, Amin M, Kang S-M, Kim Y-H, Lee I-J (2014). Evaluation of humic acid application methods for yield and yield components of mungbean. Amer. J. of Plant Sci., 5: 2269-2276.

Yakhin OI, Lubyanov AA, Yakhin IA, Brown PH (2017). Biostimulants in Plant Science: A Global Perspective. Front. Plant Sci., 7: 2049. الملخص العربى

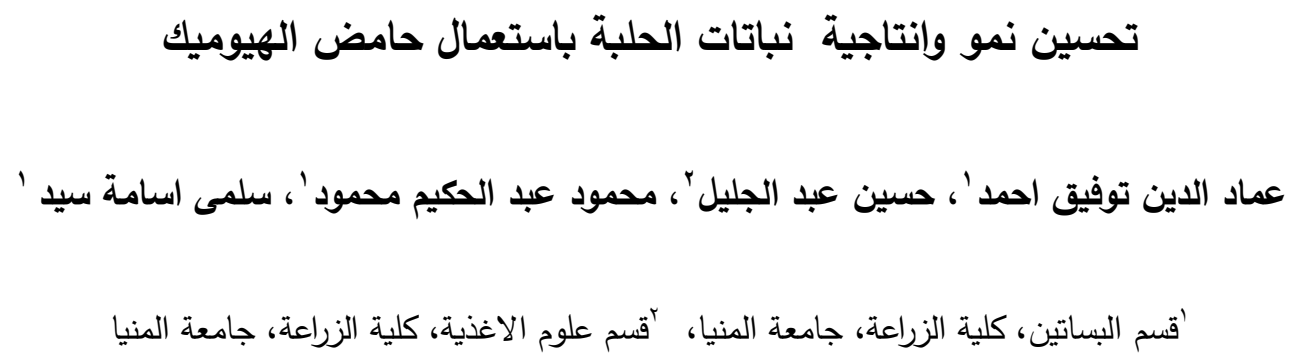

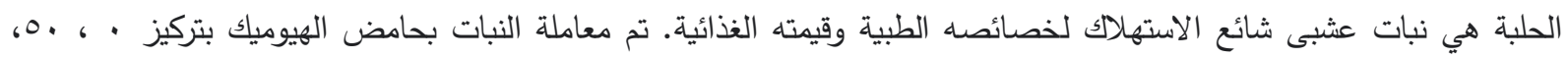

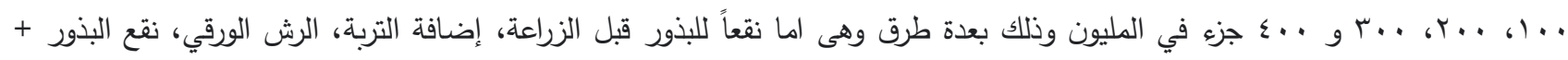
إضافة التربة، إضافة التربة + الرش الورقي. أدت كل من تركيزات الحامض وطريقة التطبيقات إلى تحسين نمو النبات وإنتاجيته بشكل كبير. علاوة على ذلك، كان هناك تفاعل كبير بين العاملين قيد الدراسة. تم زيادة ارتفاع النبات والوزن الجاف للنبات وعدد القرون/نبات ومحصول البذور بشكل عام عن طريق زيادة تركيزات حامض الهيوميك بغض النظر عن طريقة الاستخدام. كان لإضافة التربة أعلى القيم المعنوية لجميع الصفات التي تم دراستها بغض النظر عن التركيز • بشكل عام، كان للنباتات التي تم معاملتها بـ · .. جزء في المليون من الحامض كإضافة للتربة + رش على الأوراق أكبر عدد من القرون/نبات (YOV.VV) ومحصول البذور (9. . . . جم /نبات). في حين أن النباتات غير المعاملة

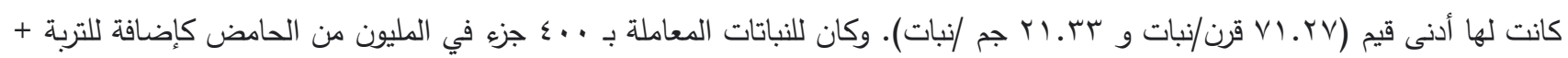

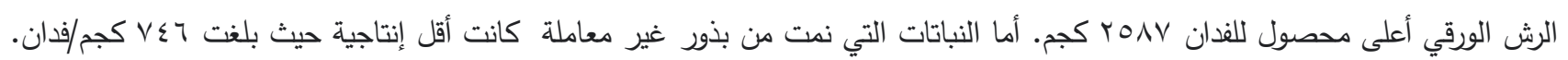
لذلك يوصى بمعاملة نبات الحلبة بحمض الهيوميك كإضافة للتربة + الرش الورقي ثلاث مرات خلال موسم النمو لزيادة محصول البذور بنحو r أضعاف مقارنة بالنباتات غير المعاملة. 